\title{
Evaluating Physicochemical Parameters, Heavy Metals, and Antibiotics in the Influents and Final Effluents of South African Wastewater Treatment Plants
}

\author{
Pardon Nyamukamba ${ }^{1 *}$, Makwena J. Molotoํ, Nikita Tavengwa², \\ Ikechukwu P. Ejidike ${ }^{1}$ \\ ${ }^{1}$ Department of Chemistry, Vaal University of Technology, Vanderbijlpark, South Africa \\ ${ }^{2}$ Molecular Sciences Institute, School of Chemistry, University of Witwatersrand, Johannesburg, South Africa
}

Received: 5 December 2017

Accepted: 7 February 2018

\begin{abstract}
The waste generated from antibiotics as influents or effluents in important waters from the rivers over their increased usage is quickly leading to societal health problems. To avoid increased accumulation of these antibiotics and their waste matter, new methods and materials are required to solve the problems before escalation. This paper aimed at evaluating treated wastewater effluent quality of three wastewater treatment plants in South Africa's Vaal Triangle: Sebokeng, Rietspruit, and Leeuwkuil. The influents and effluents were collected and analysed for heavy metals, and eight antibiotic substances for human use (erythromycin, ampicillin, cimethoprim, tetracycline, ciprofloxacin, doxycycline, chloromphemol, and sulfamethoxazol). The physicochemical parameters were also measured and the results showed that Rietspruit influent (Riet IN) had the highest salinity, total dissolved solids (TDS), electrical conductivity (EC), and turbidity. Sebokeng was found to have the lowest values for all the measured parameters except for $\mathrm{pH}$, which was lowest in Leeuwkuil influent (Lee IN). All the antibiotics were below the detection limit in all three wastewater treatment plants (WWTPs), except for sulfamethoxazole. The average concentration of sulfamethoxazole in the influents and effluents for the three investigated WWTPs ranged 39-47.8 $\mathrm{ng} \mathrm{L}^{-1}$. The lowest concentrations of magnesium (8.60 $\left.\mathrm{mg} \mathrm{L}^{-1}\right)$ and copper (0.054 $\left.\mathrm{mg} \mathrm{L}^{-1}\right)$ were found in Rietspruit (Riet MID) and Lee EFF, respectively. Lee IN had the highest concentrations of $\mathrm{Na}\left(27.98 \mathrm{mg} \mathrm{L}^{-1}\right), \mathrm{K}\left(7.48 \mathrm{mg} \mathrm{L}^{-1}\right), \mathrm{Mn}\left(0.249 \mathrm{mg} \mathrm{L}^{-1}\right)$, $\mathrm{Cu}\left(0.208 \mathrm{mg} \mathrm{L}^{-1}\right)$, Fe $\left(0.396 \mathrm{mg} \mathrm{L}^{-1}\right)$, Ni $\left(2.271 \mathrm{mg} \mathrm{L}^{-1}\right)$, and $\mathrm{Ca}\left(28.60 \mathrm{mg} \mathrm{L}^{-1}\right)$, while Riet IN had the highest Co concentration of $0.324 \mathrm{mg} \mathrm{L}^{-1}$. Sebo EFF and Sebo IN showed $11.82 \mathrm{mg} \mathrm{L}^{-1}$ of $\mathrm{Mg}$ and $2.437 \mathrm{mg} \mathrm{L}^{-1}$ of $\mathrm{Zn}$, respectively. The abundance of the metal concentrations follows the order
\end{abstract}

*e-mail: pnyamukamba@ufh.ac.za 
$\mathrm{Ca}>\mathrm{Na}>\mathrm{Mg}>\mathrm{K}>\mathrm{Zn}>\mathrm{Ni}>\mathrm{Fe}=\mathrm{Pt}>\mathrm{Co}=\mathrm{Au}>\mathrm{Mn}>\mathrm{Cu}>\mathrm{Cr}>\mathrm{As}$, indicating a higher concentration of $\mathrm{Ca}$ as $28.60 \mathrm{mg} \mathrm{L}^{-1}$, while As has the least value, which is $0.053 \mathrm{mg} \mathrm{L}^{-1}$.

Keywords: antibiotics, heavy metals, pollution, physicochemical parameters, wastewater

\section{Introduction}

The reuse of treated effluent that has been discharged into the environment from municipal wastewater treatment plants (WWTP) is increasing due to the ever-increasing demands for water as the available supplies of freshwater are decreasing due to natural disasters such as droughts and the rapid growth of the global population [1]. The final effluents from WWTPs will pose a health risk to both humans and animals when not properly treated, as they could contain several contaminants, including pharmaceuticals such as antibiotics and heavy metals. Heavy metals such as cadmium $\left(\mathrm{Cd}^{2+}\right)$ and lead $\left(\mathrm{Pb}^{2+}\right)$ are toxic inorganic contaminants found in the environment released from industries such as metal plating, mining, cadmiumnickel and lead battery production, smelting, phosphate fertilizers, and the paint industry. Their bioavailability is influenced by such physical factors as temperature, adsorption, and sequestration, as well as chemical factors that influence complexation kinetics, speciation, and lipid solubility [2].

Antibiotics are chemotherapeutic agents that inhibit the growth of microorganisms such as bacteria, protozoa, and fungi. They are complex molecules that may have different functionalities within the same molecule, meaning that under different $\mathrm{pH}$ conditions they can be cationic, anionic, neutral, or zwitterionic [3]. While antibiotics save millions of lives globally each year, their indiscriminate use poses an increasingly serious threat to public health [4]. The major pathway whereby antibiotics from human use enter the environment is the WWTP, since conventional plants do not completely remove pharmaceuticals [5]. The antibiotics end up in WWTP due to improper disposal of expired drugs (directly throwing in toilets), pharmaceutical residues from manufacture spill accidents, poultry processing, and agriculture and excretion via urine or faeces since many antibiotics are not completely metabolized and absorbed [6, 7].

The major concern of antibiotics release into the environment is the development of bacteria resistance and the resulting implications in human health [8]. Among the different classes of antibiotics, sulfamethoxazole is a representative compound of the sulfonamide bacteriostatic antibiotic family. WWTP-treated effluents are a significant source of antibiotic-resistance gene release into the downstream environment. The South African Water Act was established in 1956 and aimed to treat wastewater effluent to an acceptable standard prior to discharge into receiving water bodies. The aim of this study was to determine the occurrence of antibiotic residues in raw and treated sewage effluents from three different sewage treatment plants (Sebokeng, Rietspruit, and Leeuwkuil) in the Vaal Triangle, South Africa. Antibiotic sulfamethoxazole was used to monitor the efficacy of sewage plants to remove antibiotics.

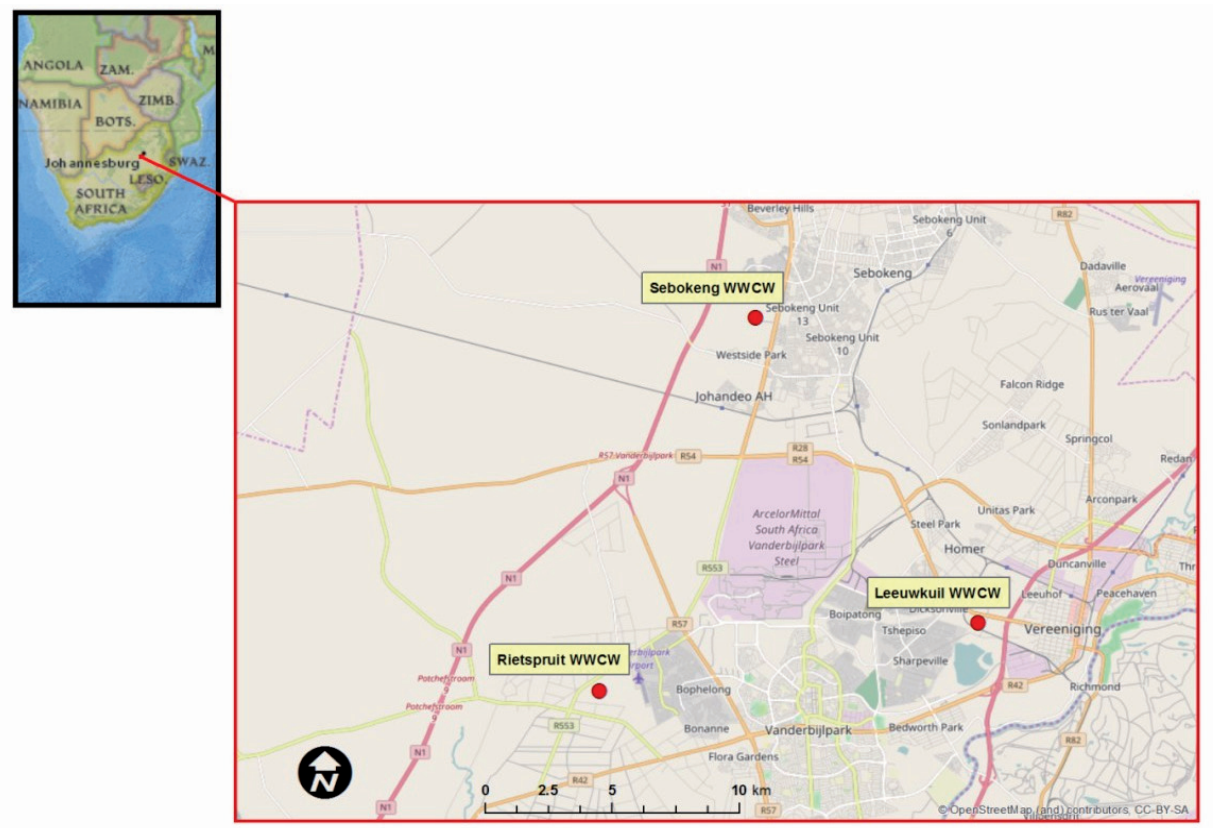

Fig. 1. Study area map showing locations of the WWTP sampling points. 


\section{Materials and Methods}

\section{Study Area Description}

This research was carried out in Vaal Triangle on Sebokeng, Rietspruit and Leeuwkuil wastewater treatment plants in South Africa as shown in Fig. 1. The Sebokeng plant (SWWTP) is situated approximately $18 \mathrm{~km}$ northwest of Vereeniging, at approximately $26^{\circ} 34^{\prime} 29.03^{\prime \prime} \mathrm{S}$ and $27^{\circ} 49^{\prime} 2.64^{\prime \prime} \mathrm{E}$. The catchment area includes some areas of the Emfuleni Local Municipality and Johannesburg Metropolitan Municipality. The catchment area includes Evaton, Evaton West, Palm Springs, Evaton North, Lakeside, Iron syde, Evaton side, Sebokeng Hills, Beverley Hills, Boitumelo, Johandeo, Poortje, Lenasia, and Orange Farm. The catchment area so far is mainly for housing, hence the origin of the wastewater is assumed to be mainly domestic. The catchment areas of the Leeuwkuil plant (LWWTP) include Sharpville, Tshepiso, Bedworth Park, Vereeniging, Three Rivers, Waldrif, and Roshnee; and Rietspruit (RWWTP) includes Bophelong, Louisrus, Movhango, and Vanderbijlpark. The final treated water from SWWTP and RWWTP is discharged into the Rietspruit River, whereas the LWWTP discharges its treated water into the Vaal.

\section{Water Sampling}

Water samples were collected from each study site on the same day. The influents and effluents were collected in prewashed polyethene bottles. Each bottle was filled to the top to exclude air that could oxidize the dissolved organics in the samples. The samples were kept in the refrigerator at $4^{\circ} \mathrm{C}$ prior to analysis. Physicochemical water parameters, which include electrical conductivity $\left(\mathrm{EC} ; \mu \mathrm{S} \mathrm{cm} \mathrm{cm}^{-1}\right), \mathrm{pH}$, total dissolved solids (TDS; $\mu \mathrm{g} \mathrm{L}^{-1}$ ), dissolved oxygen concentration (DO in $\mathrm{mg} \mathrm{L}^{-1}$ ), total suspended solids (TSS), salinity, and turbidity were measured using a Hanna multi-parameter probe (HI 9828) at $\pm 20 \mathrm{~cm}$ below the water surface.

\section{HPLC Analysis}

QA Bischoff HPLC with a UV detection system was used to separate and quantify the antibiotics. The wavelength $\left(\lambda_{\max }\right)$ for analysis of the antibiotics was set at $254 \mathrm{~nm}$ and the column temperature was $20^{\circ} \mathrm{C}$. The mobile phase composition was $50 \%$ water and $50 \%$ methanol, which was pumped at a flow rate of $2 \mathrm{~mL} \min ^{-1}$.

\section{Determining Selected Antibiotics}

In separate vials, eight antibiotics were weighed (14 mg). They were then dissolved in methanol in $10 \mathrm{~mL}$ volumetric flasks. With ciprofloxacin, a solution of methanol: acetic acid 1:9 (v/v) was used. A mixture of the stock solution was made from these eight individual antibiotic solutions by transferring $1.78 \mathrm{~mL}$ into a $100 \mathrm{~mL}$ volumetric flask and topping up to the mark with methanol.

\section{Heavy Metals Concentration Determination}

For metals' analysis we used an ICP-OES Spectro Genesis End-on-plasma from Spectro Analytical Instruments (Pty.) Ltd. (Johannesburg, South Africa). Real samples were collected from three different wastewater treatment plants under study. In the laboratory, the samples were sonicated for $15 \mathrm{~min}$ before filtering through the $0.45 \mu \mathrm{m}$ filter paper. The solution was divided into two equal portions for metal ion determination and the other portion for organic compound analysis. The solution for metal ion analysis was then acidified with $5 \%(\mathrm{v} / \mathrm{v})$. Both samples were kept in the fridge at $4^{\circ} \mathrm{C}$ until time of analysis.

\section{Results and Discussion}

The physicochemical parameters were measured and it was found that Rietspruit influent had the highest salinity, total dissolved solids (TDS), electrical conductivity (EC), and turbidity. Sebokeng effluent was found to have the lowest values in all the measured parameters except $\mathrm{pH}$, which was lowest in Leeuwkuil. Sebokeng influent had the highest $\mathrm{pH}$ of 7.07 and total dissolved solids (TSS) of 92, yet its effluent had the lowest TSS of 3, implying that the operation was efficient. Dissolved oxygen (DO) is an important parameter used for water quality control. The DO levels of the effluents (which are recommended to range between 8 and $10 \mathrm{mg} \mathrm{L}^{-1}$ by the EU) were less than $5 \mathrm{mg} \mathrm{L}^{-1}$, except for Sebokeng. This level affects the aquatic ecosystem adversely. In a similar study by Momba and co-workers, (2006) in Buffalo City and Nkonkobe Municipalities, Eastern Cape, South Africa, levels of DO oxygen were found to be less than $5 \mathrm{mg} \mathrm{L} \mathrm{L}^{-1}$, except for East London and Fort Beaufort treatment plants [9].

\section{Antibiotics Analysis}

The chromatograms (Fig. 2) for the inlet where the WWTP receives the raw water from industrial and

Table 1. Capacity, average inflow, and effluent of LWWTP, SWWTP, and RWWTP.

\begin{tabular}{|c|c|c|c|}
\hline Plant name & $\begin{array}{c}\text { Design capacity } \\
\text { (Ml/day) }\end{array}$ & $\begin{array}{c}\text { Average inflow } \\
\text { per day (Ml) }\end{array}$ & $\begin{array}{c}\text { Final effluent } \\
\text { per day (Ml) }\end{array}$ \\
\hline Leeuwkuil & 36 & 38.75 & 37.06 \\
\hline Rietspruit & 36 & 30.53 & 22.28 \\
\hline Sebokeng & 100 & 110.32 & 107 \\
\hline
\end{tabular}

ML: Megalitres 
Table 2. Physicochemical properties of both inflow and final effluent of Sebokeng, Rietspruit, and Leeuwkuil WWTPs.

\begin{tabular}{|c|c|c|c|c|c|c|}
\hline \multirow{2}{*}{$\begin{array}{c}\text { Water } \\
\text { quality } \\
\text { parameter }\end{array}$} & \multicolumn{7}{|c|}{$\begin{array}{c}\text { Sebo } \\
\text { IN }\end{array}$} & $\begin{array}{c}\text { Sebo } \\
\text { EFF }\end{array}$ & $\begin{array}{c}\text { Riet } \\
\text { IN }\end{array}$ & $\begin{array}{c}\text { Riet } \\
\text { EFF }\end{array}$ & $\begin{array}{c}\text { Lee } \\
\text { IN }\end{array}$ & $\begin{array}{c}\text { Lee } \\
\text { EFF }\end{array}$ \\
\hline $\mathrm{pH}$ & 7.07 & 6.97 & 6.88 & 6.87 & 6.72 & 6.91 \\
\hline Salinity & 0.28 & 0.16 & 0.34 & 0.23 & 0.27 & 0.28 \\
\hline TDS & 289 & 166 & 343 & 234 & 273 & 288 \\
\hline EC & 580 & 333 & 688 & 470 & 546 & 577 \\
\hline DO & 2.13 & 8.90 & 2.70 & 4.01 & 2.79 & 3.04 \\
\hline Turbidity & 102 & 4 & 90 & 16 & 72 & 38 \\
\hline TSS & 92 & 3 & 75 & 14 & 71 & 34 \\
\hline
\end{tabular}

TSS: total suspended solids, COD; chemical oxygen demand, EC: electrical conductivity, TDS: total dissolved solids, DO: dissolved oxygen, Sebo IN: Sebokeng inflow, Sebo EFF: Sebokeng effluent, Riet IN; Rietspruit inflow, Riet EFF: Rietspruit influent, Lee IN: Leeuwkuil inflow, Lee EFF: Leeuwkuil effluent

domestic waste are dirty as observed at the Lee plant. Some of the peaks were difficult to quantify as they overlapped with the matrix. From the chromatograms of the sampled areas we observed that there were subtle differences in the peaks, implying that the treatment plants receive the raw water of almost the same quality. The broad shoulders on all chromatograms could be a result of the decaying biota, which results in humic substances.

In this study, the average concentration of sulfamethoxazole in the influents and effluents for the three investigated WWTPs ranged 39-47.8 ng L-1. This concentration range does not deviate from the concentrations of this antibiotic compared to other studied WWTPs in South Africa and the rest of the world. Antibiotics were detected in appreciable amounts at the inlet of the wastewater treatment plant. Example includes: a high concentration of sulfamethoxazole $\left(59.28 \mu \mathrm{g} \mathrm{L}^{-1}\right)$ was detected at the influent of the WWTP, Northern water works, Durban, South Africa [10]; among the 12 pharmaceutical compounds investigated by Qarni and co-workers (2016), sulfamethoxazole was found in

Table 3. Some analytical regression analysis data obtained for sulfamethoxazole analysis.

\begin{tabular}{|c|c|}
\hline Parameter & Value \\
\hline Retention time (min) & 11.14 \\
\hline Regression equation & $\mathrm{y}=116.8 \mathrm{x}-8.937$ \\
\hline $\mathrm{R}^{2}$ & 0.9951 \\
\hline LOD $\left(\mathrm{mg} \mathrm{L}^{-1}\right)$ & 0.052 \\
\hline LOQ $\left(\mathrm{mg} \mathrm{L}^{-1}\right)$ & 0.179 \\
\hline Linear dynamic range $\left(\mathrm{mg} \mathrm{L}^{-1}\right)$ & $0.25-2.4$ \\
\hline
\end{tabular}

Table 4. Concentrations of sulfamethoxazole in different stages at WWTPs.

\begin{tabular}{|c|c|c|c|}
\hline \multirow{2}{*}{ Site/location } & \multicolumn{3}{|c|}{ Concentration $\left(\mathrm{ng} \mathrm{L}^{-1}\right)$} \\
\cline { 2 - 4 } & Inlet & Middle & Outlet \\
\hline Rietspruit & 39.5 & - & - \\
\hline Sebokeng & - & - & 15.0 \\
\hline Leeuwkuil & - & 57.8 & 80.3 \\
\hline
\end{tabular}

- : not detected

the influents and effluents of two hospital WWTPs in Saudi Arabia [11]; of the 22 representative antibiotics studied by Zhang et al. (2016), sulfadiazine (396 ng L'-1)

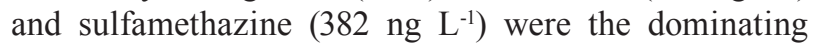
antibiotics in the influent, and the concentrations of selected antibiotics ranged from ND-41.8 ng $\mathrm{L}^{-1}$ in the effluent-receiving river [12]; and in a nationwide groundwater survey conducted by the United States Geological Survey (USGS), sulfamethoxazole appeared in $23 \%$ of the samples at an average concentration of $1.11 \mu \mathrm{g} \mathrm{L}^{-1}$.

\section{Removal Efficiency of the Treatment Plants}

The removal efficiencies of the WWTPs for the removal of the sulfamethoxazole were calculated using the following equation:

$$
\text { Removal efficiency }(\%)=\frac{\left(C_{0}-C_{e}\right)}{C_{0}} \times 100
$$

...where $\mathrm{C}_{\mathrm{o}}$ and $\mathrm{C}_{\mathrm{e}}$ are the inlet and outlet concentrations of sulfamethoxazole $\left(\mathrm{mg} \mathrm{L}^{-1}\right)$.

The wide variation of the removal ability of the three WWTPs $(-34.3 \%$ to $>99 \%)$ is not surprising as this spread has been observed across the world. In a study by Bhandari et al. (2008) in various aqueous streams of four municipal WWTPs in the Midwestern United States, the average aqueous phase concentrations for sulfamethoxazole in the raw wastewater and effluents were $18.3 \mu \mathrm{g} \mathrm{L}^{-1}$ and $3.25 \mu \mathrm{g} \mathrm{L}^{-1}$, respectively [13].

Sewage treatment plants are rarely equipped to filter these drugs from wastewater. Antibiotics are released into the water system and this often results in poor or

Table 5. Removal efficiency of the wastewater treatment plant for sulfamethoxazole.

\begin{tabular}{|c|c|}
\hline Sampling area & Removal efficiency (\%) \\
\hline Rietspruit & $>99$ \\
\hline Sebokeng & - \\
\hline Leeuwkuil & $-34.3^{\mathrm{a}}$ \\
\hline
\end{tabular}

${ }^{\mathrm{a} C a l c u l a t e d}$ from the sample collected at sedimentation and the outlet 


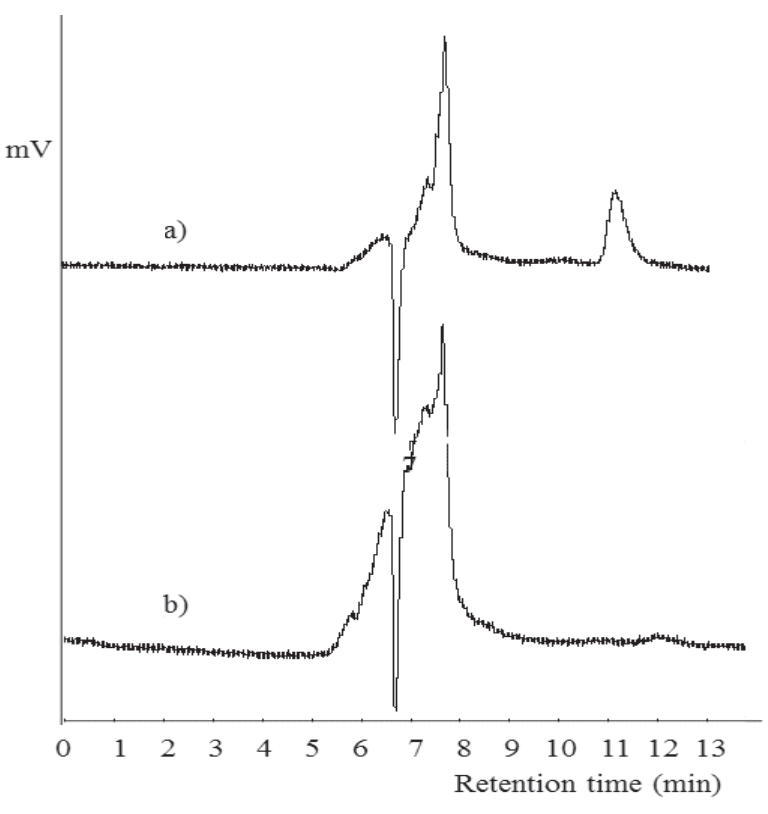

Fig. 2. Chromatograms of a) a standard solution $0.25 \mathrm{mg} \mathrm{L}^{-1}$ and b) sample.

negative removal efficiencies, as at the Lee WWTP (Table 4). The same trends were found by Zhang and co-workers (2016) in a series of the antibiotics where they observed the influent and effluent concentrations of ofloxacin to be 214 and $274 \mathrm{ng} \mathrm{L}^{-1}$, respectively [12]. This resulted in a negative removal efficiency. The authors also observed that all investigated macrolides, like spiramycin, had a lower influent concentration compared to the effluent. A good percentage (>90\%) of the antibiotics was removed after treatment [10]. The removal efficiencies of sulfamethoxazole using different methods such as activated sludge (AS) and membrane bioreactors (MBR) are shown in Table 6.

\section{Metal Analysis}

The trace metals analysed in the water samples from the three wastewater treatment plants at different stages of water treatment are shown in Table 3. We observed that the least concentration of sodium (17.26 $\left.\mathrm{mg} \mathrm{L}^{-1}\right)$, cobalt $\left(0.239 \mathrm{mg} \mathrm{L}^{-1}\right)$, manganese (0.022 mg L-1), iron (0.105 $\left.\mathrm{mg} \mathrm{L}^{-1}\right)$, zinc $\left(0.706 \mathrm{mg} \mathrm{L}^{-1}\right)$, and platinum $\left(<0.065 \mathrm{mg} \mathrm{L}^{-1}\right)$ were found in the Sebo EFF water sample, whereas gold $\left(0.240 \mathrm{mg} \mathrm{L}^{-1}\right)$, calcium
(13.04 $\left.\mathrm{mg} \mathrm{L}^{-1}\right)$, arsenic $\left(0.050 \mathrm{mg} \mathrm{L}^{-1}\right)$, and potassium (3.66 $\mathrm{mg} \mathrm{L}^{-1}$ ) were least in Sebo MID. The lowest concentrations of magnesium (8.60 $\left.\mathrm{mg} \mathrm{L}^{-1}\right)$ and copper (0.054 $\left.\mathrm{mg} \mathrm{L}^{-1}\right)$ were found in Riet EFF and Lee EFF, respectively. In a similar study, $\mathrm{Cu}$ levels in the effluent were found to range between 0.002 and $0.011 \mathrm{mg} \mathrm{L}^{-1}$ [16].

The water sample Lee IN measured the highest concentrations of $\mathrm{Na}\left(27.98 \mathrm{mg} \mathrm{L}^{-1}\right), \mathrm{K}\left(7.48 \mathrm{mg} \mathrm{L}^{-1}\right)$, $\mathrm{Mn}\left(0.249 \mathrm{mg} \mathrm{L}^{-1}\right), \mathrm{Cu}\left(0.208 \mathrm{mg} \mathrm{L}^{-1}\right)$, Fe $\left(0.396 \mathrm{mg} \mathrm{L}^{-1}\right)$, Ni (2.271 $\left.\mathrm{mg} \mathrm{L}^{-1}\right)$, and $\mathrm{Ca}\left(28.60 \mathrm{mg} \mathrm{L}^{-1}\right)$, while Riet IN measured $0.324 \mathrm{mg} \mathrm{L}^{-1}$ of Co, Sebo EFF showed $11.82 \mathrm{mg} \mathrm{L}^{-1}$ of $\mathrm{Mg}$, and Sebo INN $2.437 \mathrm{mg} \mathrm{L}^{-1}$ of $\mathrm{Zn}$. The lower to moderate concentrations measured for water samples in this study may be due to less geological interaction since it is classified as surface water [17]. The concentrations of the trace metals $\mathrm{Pb}$ and $\mathrm{Cd}$ were below their respective detection limits of $<0.01$ and $<0.001$, respectively. The reason for $\mathrm{Pb}$ concentrations being lower than the detection limit in this study could be due to the phasing out of leaded petrol in South Africa. Shamuyarira and Gumbo (2014) also found low concentrations of $\mathrm{Pb}$ in Limpopo province, South Africa [18].

$\mathrm{Cr}$ concentrations were also below detection limits of $<0.020$ in the water samples, except for Lee IN and Lee MID with $0.148 \mathrm{mg} \mathrm{L}^{-1}$ and $0.128 \mathrm{mg} \mathrm{L}^{-1}$, respectively. The chemical concentrations of analysed trace metals revealed substantial variability across the geographic spread of the sample points in the study sampling areas. The abundance of metal concentrations follows the order: $\mathrm{Ca}>\mathrm{Na}>\mathrm{Mg}>\mathrm{K}>\mathrm{Zn}>\mathrm{Ni}>$ $\mathrm{Fe}=\mathrm{Pt}>\mathrm{Co}=\mathrm{Au}>\mathrm{Mn}>\mathrm{Cu}>\mathrm{Cr}>\mathrm{As}$, indicating higher concentration of $\mathrm{Ca}$ as $28.60 \mathrm{mg} \mathrm{L}^{-1}$ while As has the least value, which is $0.075 \mathrm{mg} \mathrm{L}^{-1}$. The concentrations of the studied trace metals are higher for the inflow samples, which may be due to the transportation of wastewater from different anthropogenic activities with the runoff of rainwater and waste leachate. For the elements $\mathrm{As}, \mathrm{Cd}, \mathrm{Cu}, \mathrm{Cr}, \mathrm{Pb}$, and $\mathrm{Zn}$, the concentrations in the effluents are below National Water Act waste discharge standards, DWAF 2010 guidelines.

The concentration of As was highest in Sebo EFF and Lee MID (0.075 $\left.\mathrm{mg} \mathrm{L}^{-1}\right)$, which exceeded the WHO standard $\left(0.010 \mathrm{mg} \mathrm{L}^{-1}\right)$ (Table 3). No permissible guidelines/limits have yet been established for Co. The concentration of $\mathrm{Co}$ in the effluent ranged $0.239-0.324 \mathrm{mg} \mathrm{L}^{-1}$. However, easily dissolved cobalt

Table 6. Removal efficiencies of sulfamethoxazole from different WWTPs.

\begin{tabular}{|c|c|c|c|}
\hline WWTP & Country & Removal (\%) & Reference \\
\hline Northern Water works (Durban) & South Africa & $>90$ & {$[10]$} \\
\hline HWWTP MBR (pilot scale) & Switzerland & 7 & {$[14]$} \\
\hline MWWTP AS + chlorination & Taiwan & 20 & {$[15]$} \\
\hline
\end{tabular}

HWWTP: hospital wastewater treatment plants, MWWTP: municipal wastewater, MBR: membrane bioreactor, AS: activated sludge 


\begin{tabular}{|c|c|c|c|c|c|c|c|c|c|c|c|c|}
\hline$\tilde{U}$ & $\begin{array}{l}\overrightarrow{8} \\
\dot{\vec{v}}\end{array}$ & $\begin{array}{l}\vec{\delta} \\
\dot{\leftrightarrow} \\
\dot{v}\end{array}$ & $\begin{array}{l}\overrightarrow{8} \\
\dot{8} \\
\dot{v}\end{array}$ & $\begin{array}{l}\overrightarrow{8} \\
\dot{\nabla}\end{array}$ & $\begin{array}{l}\bar{\Xi} \\
\dot{\nabla}\end{array}$ & $\begin{array}{l}\overline{8} \\
\dot{\nabla}\end{array}$ & $\begin{array}{l}\bar{\Xi} \\
\dot{\nabla}\end{array}$ & $\begin{array}{l}\overrightarrow{\mathrm{g}} \\
\dot{\mathrm{v}}\end{array}$ & 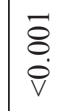 & & $\begin{array}{l}\vec{\delta} \\
\dot{\vec{v}}\end{array}$ & \\
\hline$\hat{2}$ & $\overrightarrow{\dot{\theta}}$ & $\begin{array}{l}\overrightarrow{\dot{\theta}} \\
\dot{v}\end{array}$ & $\overrightarrow{\dot{\theta}}$ & $\overrightarrow{\dot{\theta}}$ & 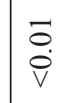 & $\overrightarrow{\dot{\theta}}$ & $\vec{\circ}$ & $\begin{array}{l}\vec{\circ} \\
\dot{v}\end{array}$ & 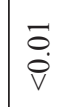 & & 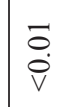 & \\
\hline$\tilde{J}$ & $\begin{array}{l}8 \\
0 \\
\infty \\
i\end{array}$ & $\begin{array}{l}\sigma \\
\infty \\
\tilde{j} \\
\end{array}$ & $\begin{array}{l}\infty \\
i \\
\text { i }\end{array}$ & 离 & $\stackrel{0}{2}$ & $\mid \begin{array}{l}\infty \\
\stackrel{\sim}{े}\end{array}$ & $\stackrel{9}{6}$ & 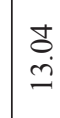 & $\underset{\substack{\infty \\
\stackrel{\sim}{\infty}}}{\infty}$ & $\begin{array}{l}8 \\
0 \\
\infty \\
i\end{array}$ & 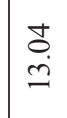 & \begin{tabular}{|l} 
氙 \\
.0
\end{tabular} \\
\hline$\vec{\psi}$ & 亲 & $\begin{array}{l}\text { to } \\
\text { ฺ̣ } \\
0\end{array}$ & 竎 & đ̃ & 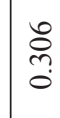 & 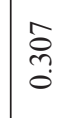 & 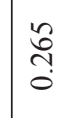 & 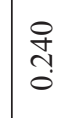 & तु & 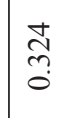 & 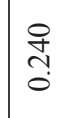 & \\
\hline $\overrightarrow{0}$ & ڤి & ڤ̆ & 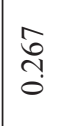 & 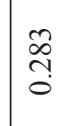 & 站 & $\underset{\text { I }}{\stackrel{g}{O}}$ & $\stackrel{\tilde{2}}{0}$ & $\stackrel{\widetilde{2}}{0}$ & $\begin{array}{l}2 \\
0 \\
0 \\
0 \\
v\end{array}$ & oे & $\frac{2}{0}$ & $\vec{\sim}$ \\
\hline$\overleftarrow{N}$ & $\stackrel{\vec{I}}{\leftrightarrows}$ & $\vec{\sigma}$ & $\begin{array}{c}0 \\
\infty \\
0 \\
0\end{array}$ & 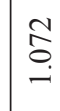 & $\frac{\ddots}{\sigma}$ & 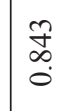 & $\underset{\tilde{F}}{\stackrel{\sim}{\sim}}$ & $\begin{array}{l}\stackrel{0}{?} \\
\stackrel{0}{0}\end{array}$ & \begin{tabular}{l}
0 \\
\multirow{2}{0}{} \\
0
\end{tabular} & $\underset{\stackrel{\tilde{f}}{+}}{\stackrel{i}{~}}$ & $\begin{array}{l}\stackrel{2}{0} \\
0\end{array}$ & \\
\hline II & ڤ̊ & 令 & 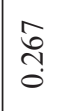 & 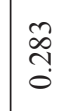 & $\frac{\text { D }}{\mathrm{O}}$ & $\frac{g}{g}$ & $\stackrel{\pi}{2}$ & $\stackrel{\pi}{0}$ & 告 & $\begin{array}{l}0 \\
\text { రి } \\
0\end{array}$ & $\begin{array}{l}n \\
0 \\
0\end{array}$ & \\
\hline$\ddot{U}$ & 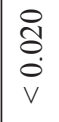 & 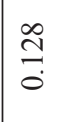 & $\frac{\infty}{\stackrel{\infty}{0}}$ & $\begin{array}{l}\stackrel{0}{0} \\
0 \\
0 \\
v\end{array}$ & $\begin{array}{l}0 \\
\delta \\
0 \\
0 \\
v\end{array}$ & $\begin{array}{l}\text { ठे } \\
0 \\
\dot{0} \\
\end{array}$ & $\begin{array}{l}\text { ठे } \\
\text {. } \\
\mathrm{v}\end{array}$ & $\begin{array}{l}\text { ठे } \\
\dot{0} \\
\mathrm{~V}\end{array}$ & $\begin{array}{l}\text { Î } \\
\dot{0} \\
\dot{v}\end{array}$ & 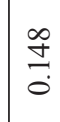 & 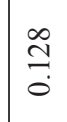 & \\
\hline $\bar{z}$ & 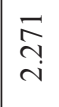 & $\begin{array}{l}8 \\
\text { ì } \\
0\end{array}$ & 吕 & శ్ & 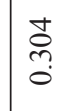 & శ్ & 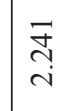 & $\begin{array}{l}\infty \\
\stackrel{0}{0} \\
\end{array}$ & \begin{tabular}{|l}
$\infty$ \\
$\stackrel{0}{0}$ \\
$\stackrel{0}{0}$
\end{tabular} & $\begin{array}{l}\overrightarrow{\hat{N}} \\
\text { in }\end{array}$ & $\begin{array}{l}\vec{f} \\
\tilde{O}\end{array}$ & \\
\hline$\vec{J}$ & 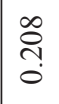 & ? & 苑 & $\frac{\vec{\sigma}}{0}$ & $\frac{n}{0}$ & $\stackrel{\overbrace{}}{\mathcal{I}}$ & $\frac{\widetilde{\alpha}}{\sigma}$ & $\frac{\widetilde{\alpha}}{\sigma}$ & $\stackrel{\tilde{2}}{0}$ & $\begin{array}{l}\infty \\
\text { ஸे } \\
0\end{array}$ & $\begin{array}{l}\text { Zे } \\
\text { Oे } \\
0\end{array}$ & .2 \\
\hline$\xi_{\Sigma}^{\xi}$ & 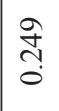 & $\underset{\infty}{\infty}$ & है & $\frac{\approx}{2}$ & శ̊ & శ్ & $\begin{array}{l}\text { to } \\
\stackrel{0}{0}\end{array}$ & $\begin{array}{l}\text { to } \\
\stackrel{0}{0}\end{array}$ & $\begin{array}{l}\widetilde{\delta} \\
\stackrel{0}{0}\end{array}$ & 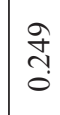 & ठี & $\frac{\pi}{3}$ \\
\hline$\sum^{\infty}$ & $\stackrel{\infty}{\stackrel{\infty}{\Xi}}$ & $\begin{array}{l}\infty \\
\sim \\
\sim\end{array}$ & กุ. & 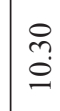 & $\begin{array}{l}\mathbb{B} \\
\infty \\
\infty\end{array}$ & 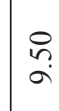 & 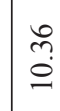 & $\begin{array}{l}\infty \\
\stackrel{\infty}{0}\end{array}$ & $\stackrel{\mathscr{O}}{=}$ & $\stackrel{\infty}{=}$ & $\begin{array}{l}8 \\
\infty \\
\infty\end{array}$ & \\
\hline$\forall$ & 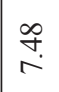 & तु. & $\begin{array}{l}\stackrel{2}{i} \\
\text { in }\end{array}$ & $\underset{6}{8}$ & त̂ & 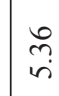 & $\underset{f}{\stackrel{N}{f}}$ & $\begin{array}{l}\stackrel{0}{0} \\
\text { in }\end{array}$ & $\underset{+}{+}$ & $\stackrel{\infty}{\stackrel{\infty}{r}}$ & $\begin{array}{l}0 \\
\stackrel{0}{0}\end{array}$ & \\
\hline$\ddot{z}$ & $\begin{array}{l}\infty \\
\stackrel{\sim}{\sim} \\
\end{array}$ & $\begin{array}{l}\infty \\
\\
\end{array}$ & $\begin{array}{l}+ \\
\infty \\
\text { i }\end{array}$ & $\frac{\AA}{\vec{\lambda}}$ & 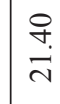 & $\begin{array}{l}\infty \\
\infty \\
\varrho\end{array}$ & $\mid \begin{array}{l}\infty \\
\infty \\
\text { i }\end{array}$ & $\mid \begin{array}{l}\infty \\
+ \\
\infty \\
\stackrel{\infty}{+}\end{array}$ & 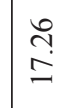 & 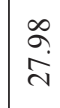 & $\begin{array}{l}\text { Iִ } \\
\stackrel{2}{I}\end{array}$ & 司 \\
\hline ن & 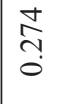 & 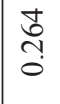 & $\underset{\stackrel{+}{+}}{\stackrel{0}{0}}$ & 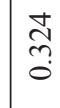 & 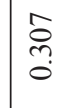 & 告 & $\begin{array}{l}\text { ¿े } \\
\text { ơ }\end{array}$ & 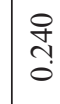 & तु & 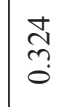 & તે & $\ddot{\theta}$ \\
\hline$\sum^{\infty}$ & 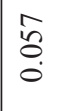 & $\begin{array}{l}n \\
\hat{o} \\
0\end{array}$ & : & ஜ̊ & : & 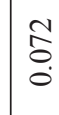 & $\begin{array}{l}\tilde{0} \\
0 \\
0\end{array}$ & . & $\begin{array}{l}n \\
0 \\
0 \\
0\end{array}$ & 㔯 & $\begin{array}{l}0 \\
0 \\
0 \\
0\end{array}$ & 弪 \\
\hline 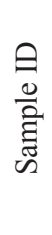 & 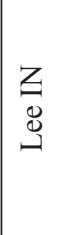 & 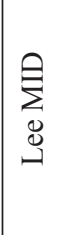 & 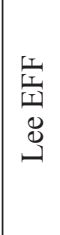 & $\frac{Z}{a}$ & $\sum_{\substack{0 \\
\sim}}^{l}$ & 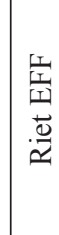 & $\begin{array}{l}Z \\
\& \\
\stackrel{0}{0} \\
\kappa\end{array}$ & 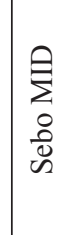 & 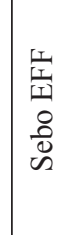 & 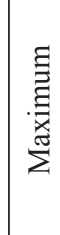 & \begin{tabular}{|l} 
言 \\
貝 \\
之
\end{tabular} & $\ddot{\ddot{z}}$ \\
\hline
\end{tabular}

compounds in water are more harmful than those that are hard to dissolve in water. When cobalt is found in the body, it is dispersed into all tissues, such as the liver, kidney, and bones [19]. The concentrations of $\mathrm{Na}$ in the effluent samples ranged between $17.26 \mathrm{mg} \mathrm{L}^{-1}$ and $27.98 \mathrm{mg} \mathrm{L}^{-1}$ but have no health implications. According to WHO (2003), most water supplies contain less than $20 \mathrm{mgL}^{-1}$ of sodium $(\mathrm{Na})$, but in some countries levels can exceed $250 \mathrm{mg} \mathrm{L}^{-1}$ [20]. The concentration of potassium (K) in the final effluents ranged $3.66-7.48 \mathrm{mg} \mathrm{L}^{-1}$. Potassium ions in living cells play a significant role in many cell functions, like growth, metabolism, repair, and capacity regulation, as well as in the electric potentials of the cell [21]. The pattern of accumulation in the effluent was in the order Lee EFF > Riet EFF > Sebo EFF. Copper concentrations were below the WHO limit, ranging from 0.054 to $0.152 \mathrm{mg} \mathrm{L}^{-1}$ in the final effluents. The maximum permissible limit by WHO is $\left(2.0 \mathrm{mg} \mathrm{L}^{-1}\right)$, which confirmed that $\mathrm{Cu}$ plays an important role in chemical and biological processes in the environment and that excessive exposure could lead to health hazards [22]. Copper enters the water system via mineral dissolution and industrial effluents, since it is used as algaecide and insecticide, and through corrosion of copper alloy water distribution pipes. $\mathrm{Cu}$ is only potentially hazardous when present at elevated levels in environmental media.

In the collected effluent water samples, the concentration of nickel ranged from 0.248 to $0.303 \mathrm{mg} \mathrm{L}^{-1}$. This concentration was above the maximum permissible limit set by WHO $\left(0.2 \mathrm{mg} \mathrm{L}^{-1}\right)$. Increased concentration and long-term exposure of humans to $\mathrm{Ni}$ can lead to decreased body weight, liver and heart damage, and skin irritation [23]. Concentrations of $\mathrm{Ni}$ become a health concern in environments where $\mathrm{pH}$ is less than 4.5. Although nickel has been an essential trace element for human and animal health, an uptake of large quantities of nickel can result in birth defects, asthma, respiratory failure, and chronic bronchitis. It can also cause various kinds of cancer on different sites within the bodies of animals [24].

Cr was only found in Lee IN $\left(0.148 \mathrm{mg} \mathrm{L}^{-1}\right)$ and Lee Mid $\left(0.128 \mathrm{mg} \mathrm{L}^{-1}\right)$ above the maximum permissible limit of $0.1 \mathrm{mg} \mathrm{L^{-1 }}$. It is reported that frequent ingestion of $\mathrm{Cr}$-contaminated water can cause anaemia and stomach cancer [25]. High $\mathrm{Cr}$ concentration has been reported to increase body weight loss and cause a reduction in the percentage of body fat, resulting in weight loss in humans [26]. The concentration of iron in water samples ranged between 0.105 to $0.396 \mathrm{mg} \mathrm{L}^{-1}$ and is present as $\mathrm{Fe}^{2+}$ in drinking water and $\mathrm{Fe}^{3+}$ in suspended form. The levels in the effluents were found in the following order: Lee EFF $>$ Riet EFF $>$ Sebo EFF. The maximum allowed concentration of iron in drinking water is $1.0 \mathrm{mg} \mathrm{L}^{-1}$ [25]. Ingestion of $\mathrm{Fe}$ in large quantities results in a condition known as 'haemochromatosis,' which results in tissue damage due to high iron concentration [25]. 
Table 8. Removal efficiencies of wastewater treatment plant for different metals.

\begin{tabular}{|c|c|c|c|}
\hline \multirow{2}{*}{ Metal } & \multicolumn{3}{|c|}{ Removal efficiency (\%) } \\
\cline { 2 - 4 } & Lee & Riet & Sebo \\
\hline $\mathrm{As}$ & -15.8 & -10.8 & -41.5 \\
\hline $\mathrm{Au}$ & 9.9 & 5.2 & 9.8 \\
\hline $\mathrm{Ca}$ & 20.3 & -1.2 & -35.2 \\
\hline $\mathrm{Cd}$ & - & - & - \\
\hline $\mathrm{Co}$ & 9.9 & 5.9 & 9.8 \\
\hline $\mathrm{Cr}$ & - & - & - \\
\hline $\mathrm{Cu}$ & 74.0 & 33.6 & 20.8 \\
\hline $\mathrm{Fe}$ & 32.6 & 47.4 & 20.5 \\
\hline $\mathrm{K}$ & 23.0 & 10.7 & 5.9 \\
\hline $\mathrm{Mg}$ & 18.5 & 7.8 & -14.1 \\
\hline $\mathrm{Mn}$ & 87.1 & 84.9 & 65.6 \\
\hline $\mathrm{Na}$ & 18.4 & 9.5 & 24.5 \\
\hline $\mathrm{Ni}$ & 89.1 & 6.2 & 88.0 \\
\hline $\mathrm{Pb}$ & - & - & - \\
\hline $\mathrm{Pt}$ & 32.6 & 47.4 & - \\
\hline $\mathrm{Zn}$ & 27.1 & 21.4 & 71.0 \\
\hline$(-) \mathrm{Eiher}$ & & & \\
\hline
\end{tabular}

(-) Either the influent or effluent was below the detection limits

On the contrary, low iron concentration can lead to nose bleeding, gastrointestinal infection, and myocardial infarction [27].

The concentration of zinc in all the water samples ranged between 0.706 and $2.437 \mathrm{mg} \mathrm{L}^{-1}$. The permissible limit of zinc in water according to WHO standards is $3.0 \mathrm{mg} \mathrm{L}^{-1}$. The $\mathrm{Zn}$ levels in the effluents ranged between 0.706 to $0.843 \mathrm{mg} \mathrm{L}^{-1}$ in the following order: Riet EFF $>$ Lee EFF $>$ Sebo EFF. Zinc is one of the important trace elements that play a vital role in the physiological and metabolic process of many organisms. Very high concentrations may cause a bitter taste and opalescence in alkaline water [17]. Zinc may be added to the environment anthropogenically through industrial activities like engine wear, exhaust emissions, waste combustion, and the use of sewage sludge from industrial areas as fertilizer [28].

Calcium is a major constituent of different types of rock. Hence it is present in natural waters ranging from zero to several hundred milligrams per litre depending on the source and treatment of the water [17]. Causes for hardness in water and incrustation in boilers are due to the presence of calcium. Its levels in the studied effluents ranged in the order: Sebo EFF $<$ Riet EFF $<$ Lee EFF. The concentration was in the range 13.04 to $22.80 \mathrm{mg} \mathrm{L}^{-1}$.
The overall removal efficiency of metals at Leeuwkuil wastewater treatment plant was 30\%, followed by Rietspruit (20.62\%) and lastly Sebokeng (17.32\%). For most individual metals, removal efficiency was very low $(<<50 \%)$, probably due to the operation of the treatment plants under stress, design weakness, and overloaded capacity. Sebokeng and Leeuwkuil treatments plants receive water that is more than the design capacity, as shown in Table 1. In another study by Morrison et al., (2001), they found that efficiency of the Keiskammahoek treatment plant was poor, resulting in the discharge of raw sewage due to inadequate treatment works, a malfunctioning pump station, and poor planning for expansion [29].

\section{Conclusions}

Sulfamethoxazole was the only antibiotic out of the eight studied antibiotics that was detected in the wastewater of the three WWTPs and was above the LOD of $52 \mu \mathrm{g} \mathrm{L}^{-1}$. There was a wide spectrum of removal efficiencies, ranging from poor to good for LWWTP (-34.8\%) and RWWTP (> 99\%), respectively. The current wastewater treatment at the three sites studied during our study was not sufficient for the removal of heavy metals, since only three of the sixteen measured heavy metals at both LWWTP and SWWTP and one at RWWTP were eliminated with efficiencies above $60 \%$. The highest concentrations of most metals were found in Leeuwkuil wastewater. Among the metals studied, the most abundant element was $\mathrm{Ca}\left(28.60 \mathrm{mg} \mathrm{L}^{-1}\right)$ and the lowest was arsenic $\left(0.053 \mathrm{mg} \mathrm{L}^{-1}\right)$. In future, we will investigate seasonal variations of the heavy metals detected in this study.

\section{Acknowledgements}

The authors wish to express their appreciation to Vaal University of Technology for sponsoring the research, and Leeuwkuil, Rietspruit, and Sebokeng wastewater treatment plant staffs for their technical assistance. The assistance of Dr. Olufemi Ademoegun and Mr. Agoro of the Department of Chemistry, Fort Hare University is also gratefully acknowledged.

\section{Conflict of Interest}

The authors declare no conflict of interest.

\section{References}

1. SINGH S.N., SRIVASTAV G., BHATT A. Physicochemical Determination of Pollutants in wastewater in Dheradun. Current World Environment, 7 (1), 133, 2012. 
2. CHIGOR V.N, SIBANDA T., OKOH A.I. Studies on the bacteriological qualities of the Buffalo River and three source water dams along its course in the Eastern Cape Province of South Africa. Environmental Science and Pollution Research, 20 (6), 4125, 2013.

3. ANDERSSON D.I., HUGHES D. Microbiological effects of sublethal levels of antibiotics. Nature Reviews Microbiology 12, 465, 2014.

4. NCUBE N.B.Q., SOLANKI G.C., KREDO T., LALLOO R. Antibiotic prescription patterns of South African general medical practitioners for treatment of acute bronchitis. SAMJ: South African Medical Journal 107 (2), 119, 2017.

5. ROSAL R., RODEA-PALOMARES I., BOLTES K., FERNA'NDEZ-PIN ${ }^{\sim}$ AS F., LEGANE' S.F., PETRE A. Ecotoxicological assessment of surfactants in the aquatic environment: combined toxicity of docusate sodium with chlorinated pollutants. Chemosphere 81 (2), 288, 2010.

6. LI W.C. Occurrence, sources, and fate of pharmaceuticals in aquatic environment and soil. Environmental Pollution, 187, 193, 2014.

7. HEUER H., SCHMITT H., SMALLA K. Antibiotic resistance gene spread due to manure application on agricultural fields. Current Opinion in Microbiology, 14 (3), 236, 2011.

8. VENTOLA C.L. MS. The Antibiotic Resistance Crisis Part 1: Causes and Threats. Pharmacy \& Therapeutics, 40 (4), 277, 2015.

9. MOMBA M.N.B., OSODE A.N., SIBEWU M. The impact of inadequate wastewater treatment on the receiving watebodies - Case study: Buffalo City and Nkonkobe Municipalities of the Eastern Cape Province. Durban, South Africa: Water SA, Water Institute of South Africa (WISA) Bennial Conference. 32, 0378, 2006.

10. MATONGO S., BIRUNGI G., MOODLEY B., NDUNGU P. Occurrence of selected pharmaceuticals in water and sediment of Umgeni River, KwaZulu-Natal, South Africa, Environ Sci Pollut Res. 22, 10298, 2015

11. QARNI H.A., COLLIER P., O'KEEFFE J., AKUNNA $\mathrm{J}$. Investigating the removal of some pharmaceutical compounds in hospital wastewater treatment plants operating in Saudi Arabia, Environmental Science and Pollution Research. 23 (13), 13003, 2016.

12. ZHANG C., WANG L., GAO X., HE X., Antibiotics in WWTP discharge into the Chaobai River, Beijing, Archives of Environmental Protection, 42, 48, 2016.

13. BHANDARI A., CLOSE L.I., KIM W., HUNTER R.P., KOCH D.E., SURAMPALLI R.Y. Occurrence of Ciprofloxacin, Sulfamethoxazole, and Azithromycin in Municipal Wastewater Treatment Plants, Practice Periodical of Hazardous, Toxic, and Radioactive Waste Management, 12, 275, 2008.

14. KOVALOVA L., SIEGRIST H., SINGER H., WITTMER A., MCARDELL C. Hospital wastewater treatment by membrane bioreactor: performance and efficiency for organic micropollutant elimination. Environ Sci Technol. 46 (3), 1536, 2012.

15. LIN A.Y., LIN C.F., TSAI Y.T., LIN H.H., CHEN J., WANG X.H., YU T.H. Fate of selected pharmaceuticals and personal care products after secondary wastewater treatment processes in Taiwan. Water Sci Technol. 62, 2450, 2010

16. RICHARDS H., MOOLLAN R.W., BECERI R., MOCHE D., RUS H. An overview of the heavy metal concentrations found in municipal wastewaters and wastewater sludges in the city of Cape Town. Proceedings of the 2004 Water Institute of Southern Africa (WISA) Biennial Conference, ISBN: 1-920-01728-3.

17. GYAMFI E.T., ACKAH M., ANIM A.K., HANSON J.K, KPATTAH L, ENTI-BROWN S., ADJEI-KYEREME Y., NYARKO E.S. Chemical analysis of potable water samples from selected suburbs of Accra, Ghana. Proceedings of the International Academy of Ecology and Environmental Sciences. 2, 118, 2012.

18. SHAMUYARIRA K.K., GUMBO J.R. Assessment of Heavy Metals in Municipal Sewage Sludge: A Case Study of Limpopo Province, South Africa. International Journal of Environmental Research and Public Health 11 (3), 2569, 2014.

19. SANSONE V., PAGANI D., MELATO M. The effects on bone cells of metal ions released from orthopaedic implants. A review. Clinical Cases in mineral and bone metabolism 10 (1), 34, 2013.

20. KHATER A.E.M., Al-JALOUD A., El-TAHER A. Quality Level of Bottled Drinking Water Consumed in Saudi Arabia. Journal of Environmental Science and Technology 7 (2), 90, 2014.

21. NKANSAH M.A., EPHRAIM J.H. Physicochemical Studies of Water from Selected Boreholes in the Bosomtwi-Atwima-Kwanwoma District of Ghana. The Pacific Journal of Science and Technology 10 (2), 643, 2009.

22. EL-SAYED M., SALEM. Hydrochemical assessments of surface Nile water and ground water in an industry area - South West Cairo. Egyptian Journal of Petroleum 24 (3), 277, 2015.

23. JAMES O.O., NWAEZE K., MESAGAN E., AGBOJO M., SAKA K.L. OLABANJI D.J. Concentration of heavy metals in five pharmaceutical effluents in Ogun State, Nigeria. Journal of Environment Pharmacology and Life Sciences. 2 (8), 84, 2013.

24. JAVED M., USMANI N. Assessment of heavy metal $(\mathrm{Cu}$, $\mathrm{Ni}, \mathrm{Fe}, \mathrm{Co}, \mathrm{Mn}, \mathrm{Cr}, \mathrm{Zn}$ ) pollution in effluent dominated rivulet water and their effect on glycogen metabolism and histology of Mastacembelus armatus. SpringerPlus, 2, 390, 2013.

25. WHO, Guidelines for Drinking Water Quality Fourth Edition, World Health Organization. ISBN 978-92-4154815-1, 2011.

26. PENG M., YANG X. Controlling diabetes by chromium complexes: The role of the ligands. Journal of Inorganic Biochemistry. 146 (9), 97, 2015.

27. BABALWA T., OYEDEJI O., EJIDIKE I.P., OYEDEJI A. Evaluation of trace metal profile in Cymbopogon validus and Hyparrhenia hirta used as traditional herbs from environmentally diverse region of Komga, South Africa. Journal of Analytical Methods in Chemistry, 2016, 1, 2016.

28. EJIDIKE I.P., ONIANWA P.C. Assessment of trace metals concentration in tree barks as indicator of atmospheric pollution within Ibadan City, South-West, Nigeria. Journal of Analytical Methods in Chemistry. 2015, 1, 2015.

29. MORRISON G., FATOKI O.S., PERSSON L., EKBERG A. Assessment of the impact of point source pollution from the Keiskammahoek Sewage Treatment Plant on the Keiskamma River - $\mathrm{pH}$, lelctrical conductivity, oxygendemanding substrate (COD) and nutrients. South Africa: Water SA. 475, 2001. 